\title{
A SINGLE CLASS OF NEUROTENSIN RECEPTORS WITH HIGH AFFINITY IN NEUROBLASTOMA $\times$ GLIOMA NG108-15 HYBRID CELLS THAT MEDIATE FACILITATION OF SYNAPTIC TRANSMISSION ${ }^{1}$
}

\author{
YUZO NAKAGAWA, ${ }^{2}$ HARUHIRO HIGASHIDA, AND NAOMASA MIKI \\ Department of Pharmacology, Cancer Research Institute, Kanazawa University, 13-1 Takaramachi, Kanazawa 920, Japan
}

Received October 21, 1983; Revised February 8, 1981; Accepted February 9, 1981

\begin{abstract}
Receptor binding of $\left[{ }^{3} \mathrm{H}\right]$ neurotensin was examined on membrane preparations derived from neuroblastoma $\times$ glioma NG108-15 hybrid cells. The specific binding was saturable and reversible, and a dissociation constant $\left(K_{\mathrm{d}}\right)$ was calculated to be about $0.24 \mathrm{nM}$ from the rate constants. Scatchard analysis of neurotensin binding at equilibrium revealed a single class of binding sites with a $K_{\mathrm{d}}$ of $0.86 \mathrm{nM}$ and a maximal binding capacity $\left(B_{\max }\right)$ of $250 \mathrm{fmol} / \mathrm{mg}$ of protein $(7700$ receptor sites/cell). [D-Arg ${ }^{9}$ ]-Neurotensin had a high affinity $\left(\mathrm{IC}_{50}=0.5 \mathrm{nM}\right)$ for the neurotensin receptors, but $\left[\mathrm{D}-\mathrm{Ph} \mathrm{e}^{11}\right]$-neurotensin had a lower affinity $\left(\mathrm{IC}_{50}=280 \mathrm{nM}\right)$, while angiotensin II and bradykinin had almost no affinity for $\left[{ }^{3} \mathrm{H}\right]$ neurotensin-binding sites.

Under similar conditions $\left[{ }^{3} \mathrm{H}\right]$ neurotensin binding to mouse and rat brain synaptosomal fractions showed two binding sites with high (0.86 and $0.44 \mathrm{nM})$ and low (13 and $19 \mathrm{nM})$ affinities.

We have examined several possible physiological consequences of neurotensin receptor binding. Neurotensin $(10 \mu \mathrm{M})$ exhibited no influence on adenylate cyclase activity, ${ }^{45} \mathrm{Ca}$ uptake, or ${ }^{32} \mathrm{P}_{\mathrm{i}}$ incorporation into phosphatidylinositol fractions of NG108-15 cells. Electrophysiological study of isolated NG108-15 cells revealed neurotensin-induced transient hyperpolarization followed by sustained depolarization with enhanced membrane excitability. Application of neurotensin to NG108-15 cells that had formed synapses with cultured striated muscle cells caused a considerable increase in frequency of miniature endplate potentials from the muscle cells. These data show that NG108-15 cells possess a single class of neurotensin receptors similar to a high affinity site of synaptosomal membranes from the murine brains. The results suggest that neurotensin facilitation of synaptic transmission is mediated through receptors coupled to ionotropic processes rather than to cellular metabolic ones.
\end{abstract}

Neurotensin, a tridecapeptide which was first isolated from bovine hypothalamus extracts (Carraway and Leeman, 1973), has wide physiological and pharmacological activity (Leeman and Carraway, 1982). Neurotensin is present in the synaptosomal fraction of brain homogenates (Uhl and Snyder, 1976) and probably is present in vesicles of synaptic terminals (Seybold and Maley, 1981;

\footnotetext{
1 This work was supported in part by Grants-in- $\Lambda$ id for Metaboli Response Research 57213010 and 58105002 from the Ministry of Education, Science and Culture of Japan. We are grateful to Dr. Marshall Nirenberg, National Institutes of Health, for his enthusiasm and support, in whose laboratory the initial part of this work was started by $\mathrm{H}$. H. We also wish to thank Dr. John MacDermot for participation in the early stages of this study and Mrs. Akiko Hino and Kumiko Ohzasa for their technical assistance.

${ }^{2}$ To whom correspondence should be addressed.
}

Emson et al., 1982). Its release from rat brain is calcium dependent (Iversen et al., 1978). The high affinity and reversible binding of neurotensin have been demonstrated by tritiated or iodinated neurotensin in membrane preparations of rat brains (Kitabgi et al., 1977, 1980; Uhl et al., 1977; Vincent et al., 1982), intestinal smooth muscle (Kitabgi and Freychet, 1979), human colon carcinoma cells (Kitabgi et al., 1980), and mast cells (Lazarus et al., 1977a, b; Rivier et al., 1977). This suggests the presence of physiological neurotensin receptor sites. Data extracellularly recorded show inhibitory effects of locally applied neurotensin on cells of cerebellum (McCarthy et al., 1979; Marwaha et al., 1980) and locus ceruleus (Young et al., 1978), and excitatory action on cells in the bed nucleus of the stria terminalis (Sawada et al., 1980), spinal cord (Miletic and Randic, 1979), and lumbar horn (Henry, 1982). 'These data strongly suggest 
that neurotensin may serve as a neurotransmitter and/ or neuromodulator in the CNS.

Facilitation of synaptic transmission by neurotensin as well as by angiotensin II and bradykinin has been reported at synapses between NG108-15 (neuroblastoma $\times$ glioma) hybrid and striated muscle cells in a preliminary form (Higashida et al., 1978). NG108-15 cells possess functional receptors for neurotensin and provide an in vitro system to investigate the neurotensin effect on neuronal functions at the membrane level of a single cell.

NG108-15 hybrid cells express various neurotransmitter receptors, each of which corresponds to one subtype of receptor characterized in normal nervous tissues (Nirenberg et al., 1983). Receptors in NG108-15 cells can be classified into three different types with respect to receptor-mediated respones: (1) opiate receptors (Klee and Nirenberg, 1974; Sharma et al., 1975; Traber et al., $1975 \mathrm{~b}), \alpha_{2}$-adrenergic receptors (Sabol and Nirenberg, 1979; Haga and Haga, 1981; Kahn et al., 1982), and prostaglandin $(\mathrm{PG}) \mathrm{E}_{1}$ receptors (Kenimer and Nirenberg, 1981; Kenimer, 1982) which preferentially couple to adenylate cyclase; (2) serotonin receptors dominantly linked to ionic channels (Christian et al., 1978; MacDermot et al., 1979); and (3) muscarinic receptors (Traber et al., 1975a; Burgermeister et al., 1978; Christian et al., 1978) and $\mathrm{PGD}_{2}$ receptors (Higashida et al., 1984) mediating effects on both cyclase and membrane potentials. We have attempted to clarify receptor-coupling modes of neurotensin in NG108-15 cells and to determine to which class the neurotensin receptors belong.

In this report, we have demonstrated the existence of a specific neurotensin-binding site in NG108-15 cells with $\left[{ }^{3} \mathrm{H}\right]$ neurotensin and compared it with those of mouse or rat brains. Physiological effects of neurotensin on adenylate cyclase [E.C.4.6.1.1.], phosphatidylinositol turnover, ${ }^{45} \mathrm{Ca}$ uptake, membrane potentials in NG10815 cells, and synaptic transmission at NG108-15-myotube synapses have also been examined.

\section{Materials and Methods}

Materials. The following materials were purchased from the indicated sources: tissue culture media from Grand Island Biological Co. (Grand Island, NY), fetal calf serum (FCS) from Micro Biological Associates (Bethesda, MD); dibutyryl cyclic AMP (Bt $\mathrm{B}_{2} \mathrm{cAMP}$ ) from Yamasa Shoyu Co. (Choshi, Japan); $\mathrm{PGE}_{1}$ from Ono Pharmaceutical Co. (Osaka, Japan); neurotensin, bradykinin, and angiotensin II from Protein Research Foundation (Osaka, Japan). Two neurotensin analogues, [D$\left.\mathrm{Arg}^{9}\right]$ - and [D-Phe $\left.{ }^{11}\right]$-neurotensin, were the kind gift of Dr. Jean Rivier, The Salk Institute, San Diego, CA. $\left[{ }^{3} \mathrm{H}\right]$ Neurotensin, $\left[{ }^{3} \mathrm{H}\right] \mathrm{ATP}$, and $\left[{ }^{32} \mathrm{P}\right]$ orthophosphate were obtained from New England Nuclear (Boston, MA), and ${ }^{45} \mathrm{CaCl}_{2}$ was from Amersham Int. Plc. (Buckinghamshire, England). All other reagents were of highest available purity from standard sources.

Cell culture. Parental neuroblastoma N18TG-2, glioma C6BU-1, and their hybrid NG108-15 cells (Nirenberg et al., 1983) were grown in flasks (Falcon, $75-\mathrm{cm}^{2}$ surface area) in Dulbecco's modified Eagle's medium (DMEM) containing $44 \mathrm{mM} \mathrm{NaHCO}_{3}$ and $5 \%$ FCS in a humidified atmosphere of $90 \%$ air, $10 \% \mathrm{CO}_{2}$ at $37^{\circ} \mathrm{C}$. For the hybrid cells, $1 \times 10^{-4} \mathrm{M}$ hypoxanthine, $1 \times 10^{-6} \mathrm{M}$ aminopterin, and $1.6 \times 10^{-5} \mathrm{M}$ thymidine were added as described previously (MacDermot et al., 1979). Before reaching $70 \%$ confluency, cells were detached by incubating them with $10 \mathrm{ml}$ of Dulbecco's phosphate-buffered saline without $\mathrm{Ca}^{2+}$ and $\mathrm{Mg}^{2+}(\mathrm{PBS}(-))$ for $5 \mathrm{~min}$ at $37^{\circ} \mathrm{C}$ and subcultured by reseeding at a density of 200,000 cells/ flask or as indicated in $35-$ or $60-\mathrm{mm}$ dishes. In some experiments, the cells were cultured in the differentiation medium (DMEM, 2\% FCS, hypoxanthine, and thymidine) supplemented with $1 \mathrm{mM} \mathrm{Bt} \mathrm{C}_{2} \mathrm{cAMP}$ or $10 \mu \mathrm{M} \mathrm{PGE}_{1}$ and $1 \mathrm{~mm}$ theophylline. For collecting a great mass of cells, the cultures were maintained until they approached $100 \%$ confluency by changing the medium once or twice daily to maintain the $\mathrm{pH}$ between 7.2 and 7.4. After removing medium, cultures were washed three times with PBS(-) and incubated for $5 \mathrm{~min}$. Cells were harvested by agitation, collected by centrifugation at $300 \times g$ for 5 min at $25^{\circ} \mathrm{C}$, and stored at $-80^{\circ} \mathrm{C}$ until use.

Preparation of membrane fraction. The frozen NG10815 cells were thawed and suspended in $5 \mathrm{ml}$ of a cold hypotonic solution (5 mM Tris- $\mathrm{HCl}, \mathrm{pH} 7.5$, containing $5 \mathrm{mM} \mathrm{MgSO}_{4}$ ). The cells were allowed to swell for $20 \mathrm{~min}$ and were homogenized with a Teflon-glass homogenizer. Intact cells and nuclei pellets were removed by centrifugation at $500 \times g$ for $10 \mathrm{~min}$ at $4^{\circ} \mathrm{C}$. The supernatant was then centrifuged at $30,000 \times g$ for $60 \mathrm{~min}$ at $4^{\circ} \mathrm{C}$, and the pellet was resuspended in $50 \mathrm{~mm}$ Tris- $\mathrm{HCl}$ buffer, $\mathrm{pH} 7.5$, with $15 \mathrm{~mm} \mathrm{MgCl}{ }_{2}$. This procedure was repeated twice. The final pellet was kept frozen at $-80^{\circ} \mathrm{C}$ with no loss of binding.

The synaptosomal fraction of rat and mouse brains was prepared by the method of Gray and Whittaker (1962). Brains were homogenized with $10 \mathrm{vol}$ of $0.32 \mathrm{M}$ sucrose using a glass homogenizer with a Teflon pestle. After centrifugation at $1,000 \times \mathrm{g}$ for $10 \mathrm{~min}$ at $4^{\circ} \mathrm{C}$, the supernatant was further centrifuged at $17,000 \times g$ for 55 min. Crude mitochondrial fractions $\left(\mathrm{P}_{2}\right)$ were resuspended in distilled water, layered on a discontinuous sucrose gradient, and centrifuged at $55,000 \times g$ for 90 min using a Beckman rotor (SW 27). The synaptosomal fraction recovered at the interface between 0.8 and 1.2 M sucrose was diluted with $50 \mathrm{~mm}$ Tris- $\mathrm{HCl}$ buffer (containing $1 \mathrm{~mm}$ EDTA, pH 7.5) and centrifuged at 100,000 $\times g$ for $60 \mathrm{~min}$. The pellet was washed twice by repeating centrifugation and stored at $-80^{\circ} \mathrm{C}$.

Assay of $\left[{ }^{3} \mathrm{H}\right]$ neurotensin binding. Cell or brain membrane fractions were thawed and resuspended in $50 \mathrm{mM}$ Tris- $\mathrm{HCl}(\mathrm{pH} 7.5)$ buffer to a protein concentration of about $15 \mathrm{mg} / \mathrm{ml}$. Neurotensin binding was performed according to the procedure of Kitabgi ct al. (1977), using $\left[{ }^{3} \mathrm{H}\right]$ neurotensin $(65.5 \mathrm{Ci} / \mathrm{mmol})$. Aliquots $(0.2 \mathrm{ml})$ of the final binding mixture consisting of $50 \mathrm{mM}$ Tris- $\mathrm{HCl}(\mathrm{pH}$ $7.5), 0.5 \%$ bovine serum albumin, various concentrations of $\left[{ }^{3} \mathrm{H}\right]$ neurotensin, and membrane fraction (usually about $0.7 \mathrm{mg}$ of protein) in plastic tubes were incubated for $5 \mathrm{~min}$ at $25^{\circ} \mathrm{C}$. The incubation was terminated by adding $5 \mathrm{ml}$ of ice-cold $50 \mathrm{~mm}$ Tris- $\mathrm{HCl}$ to each, and the reaction mixtures were filtered on Whatman $\mathrm{GF} / \mathrm{B}$ filters. The filters were washed three times, dried, and rinsed in a toluene-Triton X-100-based scintillation 
fluid. After immersing them for $12 \mathrm{hr}$ at room temperature, radioactivity was measured with a Beckman liquid scintillation spectrometer. Unlabeled neurotensin (10 $\mu \mathrm{M}$ ) was added to duplicate tubes to estimate nonspecific binding. Specific binding was usually about 60 to $70 \%$ of total bound radioactivity. Nonlinear Scatchard plots of murine brains were calculated by a computer simulation of a two-site binding model described by Feldman (1972). According to characteristics of this simulation, correlation coefficients of two lines generated between data were obtained. Protein was determined by the method of Lowry et al. (1951) with bovine serum albumin as the standard.

Assay of adenylate cyclase activity. Measurement of adenylate cyclase activity was performed as described previously (Higashida et al., 1981b, 1984). The membrane fractions of NG108-15 cells were used for the enzyme source.

Assay of phosphatidylinositol turnover. Assays of lipid phosphorus were measured as described by Yano et al. (1983). Briefly, NG108-15 cells were washed twice with PBS and incubated in $2 \mathrm{ml}$ of PBS containing $\left[{ }^{32} \mathrm{P}\right]$ orthophosphate $(33 \mathrm{Ci} / \mathrm{ml})$ at $37^{\circ} \mathrm{C}$ for $60 \mathrm{~min}$. The cells were exposed to $10 \mu \mathrm{M}$ neurotensin for $15 \mathrm{~min}$. The reactions were terminated by adding $2 \mathrm{ml}$ of chloroform/ methanol $(1: 2, \mathrm{v} / \mathrm{v})$. The phospholipids were separated by two-dimensional chromatography on silica gel $\mathrm{H}$ plates with $2.5 \%$ magnesium acetate, using chloroform/ methanol/13.5 $\mathrm{N}$ ammonia water $(65: 35: 5.5, \mathrm{v} / \mathrm{v})$ in the first direction, and chloroform/acetone/methanol/acetic acid/water $(3: 4: 1: 1: 0.5, \mathrm{v} / \mathrm{v})$ in the second direction. Lip- ids on the plate were visualized by exposing the plate to iodine vapor. The spots were scraped off, and the radioactivity in each spot was measured.

${ }^{45} \mathrm{Ca}$ uptake. The uptake of ${ }^{45} \mathrm{CaCl}_{2}$ by cultured cells was measured by a slight modification of the method of Ohsako and Deguchi (1981). NG108-15 cells were grown in the presence of $1 \mathrm{mM} \mathrm{Bt} \mathrm{C}_{2} \mathrm{AMP}$ on polyornithinecoated dishes $(60 \mathrm{~mm})$ prepared as described by Miki et al. (1981). Cultures were washed with $1.5 \mathrm{ml}$ of buffer A (20 mM Tris- $\mathrm{HCl}, \mathrm{pH} 7.4,5.4 \mathrm{~mm} \mathrm{KCl}, 0.8 \mathrm{mM} \mathrm{MgSO}_{4}$, $150 \mathrm{~mm} \mathrm{NaCl}, 1.8 \mathrm{mM} \mathrm{CaCl}_{2}$, and $20 \mathrm{~mm}$ glucose) and incubated in $1.8 \mathrm{ml}$ of buffer $\mathrm{A}$ at $25^{\circ} \mathrm{C}$ for $30 \mathrm{~min}$. The reaction was started by adding of $200 \mu \mathrm{l}$ of buffer $\mathrm{A}$ containing $4 \mu \mathrm{Ci}$ of ${ }^{45} \mathrm{CaCl}_{2}$ in the presence or absence of $10 \mu \mathrm{M}$ neurotensin. After incubating for the indicated period, the medium was removed by aspiration, and dishes were washed with $3 \mathrm{ml}$ of ice-cold buffer containing $150 \mathrm{mM} \mathrm{NaCl}, 5 \mathrm{~mm} \mathrm{CaCl}, 0.1 \mathrm{~mm} \mathrm{LaCl}$, and 20 $\mathrm{mM}$ Tris- $\mathrm{HCl}, \mathrm{pH}$ 7.4. The washing procedure was performed within $20 \mathrm{sec}$. The washed cells were suspended in $1.5 \mathrm{ml}$ of $0.05 \%$ deoxycholate and the radioactivity was measured with a liquid scintillation counter.

Electrophysiological measurements. NG108-15 cells used for electrophysiological studies were plated at a density of 1 to $5 \times 10^{5}$ cells $/ 35-\mathrm{mm}$ dish and were maintained in the differentiation medium supplemented with $1 \mathrm{mM} \mathrm{Bt}, \mathrm{cAMP}$ for 5 to 7 days. For synapse formation experiments, 0.5 to $2 \times 10^{5} \mathrm{NG108-15}$ cells without pretreatment were suspended in $2 \mathrm{ml}$ of DMEM (containing hypoxanthine and thymidine) with $10 \%$ heat-inactivated horse serum and then co-cultured onto
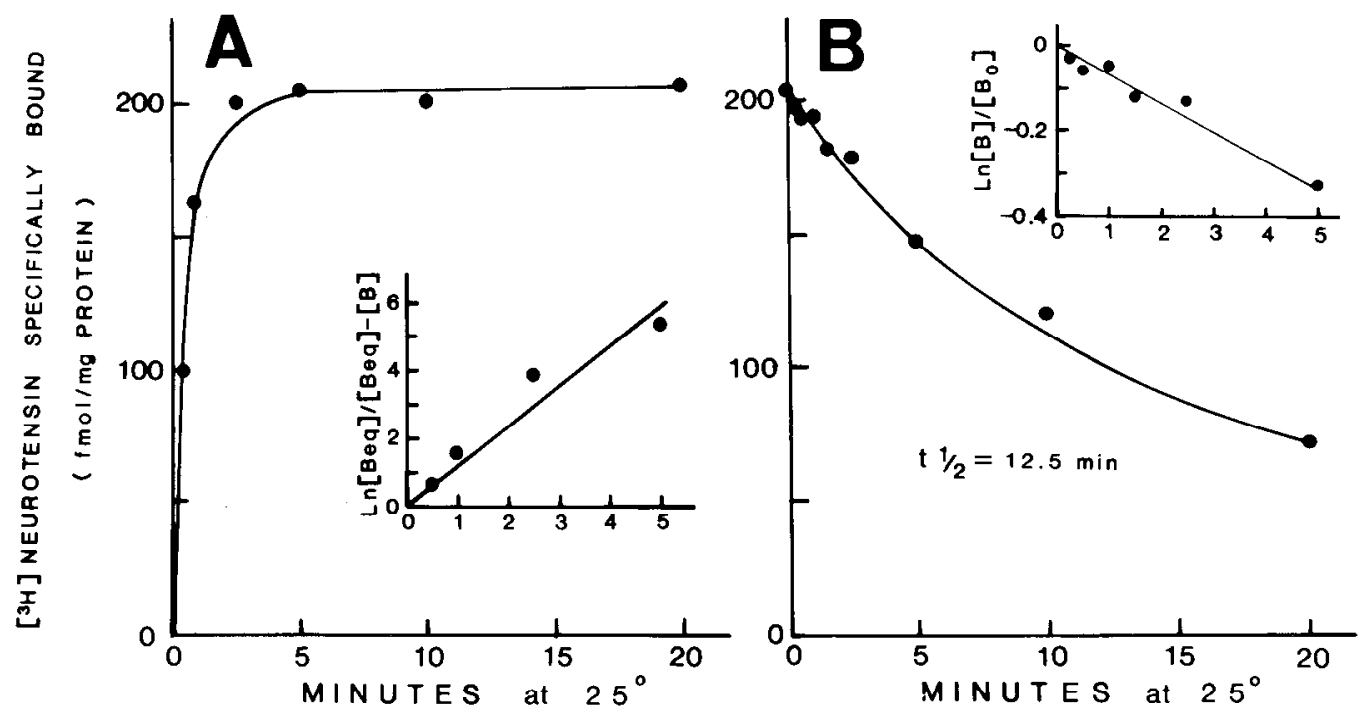

Figure 1. Time course for association and dissociation of $\left[{ }^{3} \mathrm{H}\right]$ neurotensin specific binding to NG108-15 cell membranes. $A$, Association of $\left[{ }^{3} \mathrm{H}\right]$ neurotensin specific binding to membranes $\left(0.7 \mathrm{mg}\right.$ of protein) at $25^{\circ} \mathrm{C}$ was measured at various intervals following the addition of $3 \mathrm{nM}\left[{ }^{3} \mathrm{H}\right]$ neurotensin. Specific binding was defined as the difference between binding obtained in the absence and presence of $10 \mu \mathrm{M}$ neurotensin. Each point is the quadruplicate determination of duplicate experiments. Inset, Pseudo-first-order kinetic plot of initial $\left[{ }^{3} \mathrm{H}\right]$ neurotensin specific binding. $K_{1}$ was determined by the equation $K_{1}=\left(K_{\text {obs }}-\mathrm{K}_{-1}\right) /$ $\left[{ }^{3} \mathrm{H}\right]$ neurotensin. $B$, Dissociation of specifically bound $\left[{ }^{3} \mathrm{H}\right]$ neurotensin was measured at $25^{\circ} \mathrm{C}$ following incubation with $3 \mathrm{nM}$ $\left[{ }^{3} \mathrm{H}\right]$ neurotensin to equilibrium $(20 \mathrm{~min})$. At time zero, $10 \mu \mathrm{M}$ neurotensin was added to the incubation mixture, and the reaction was terminated by filtration at indicated times. Nonspecific binding was determined in parallel samples containing $10 \mu \mathrm{M}$ neurotensin. Each point is the mean of quadruplicate determinations from duplicate experiments. Standard error of the mean is less than $5 \%$. About $75 \%$ of the $\left[{ }^{3} \mathrm{H}\right]$ neurotensin had dissociated from membranes 40 min after addition of neurotensin (not shown). Inset, First-order kinetic plot of $\left[{ }^{3} \mathrm{H}\right]$ neurotensin specific binding. $K_{-1}$ is represented by the negative slope, determined by least squares linear regression. 


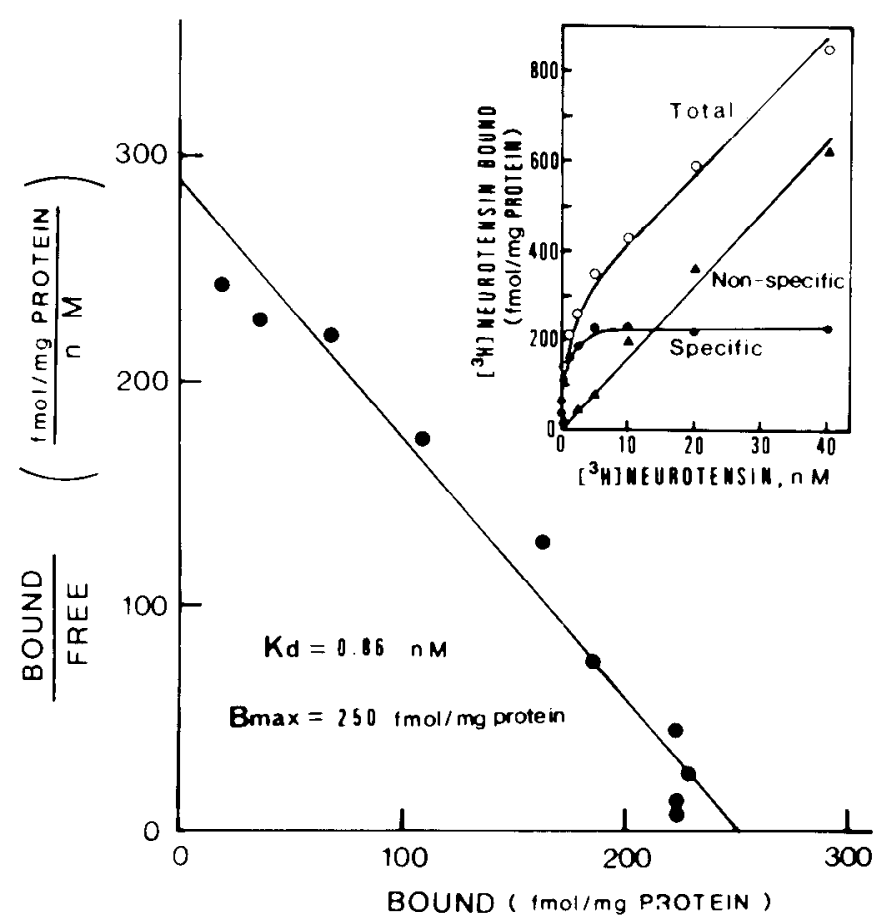

Figure 2. Scatchard plot of $\left[{ }^{3} \mathrm{H}\right]$ neurotensin binding to membranes from NG108-15 cells. The binding was measured after 5 min of incubation with membranes by increasing concentrations of $\left[{ }^{3} \mathrm{H}\right]$ neurotensin $(0.08$ to $40 \mathrm{nM})$ in the presence $(\boldsymbol{A})$ and ahsence $(\mathrm{O})$ of $10 \mu \mathrm{M}$ unlabled neurotensin at $25^{\circ} \mathrm{C}$. Specific binding (O) was defined as total binding (O) minus nonspecific binding $(\boldsymbol{\Lambda})$, which was measured in the presence of $10 \mu \mathrm{M}$ unlabeled neurotensin, as shown in the inset. The data are plotted according to Scatchard analysis. This graph is representative of two independent experiments with duplicate determinations, and the lines were determined by linear regression analysis.

the fused rat myotubes which had been cultured for 6 to 7 days (Higashida et al., 1981a, 1984). $\mathrm{PGE}_{1}(10 \mu \mathrm{M})$ and theophylline $(1 \mathrm{mM})$ were added just after starting the co-cultures. Intracellular recording techniques of membrane potentials of $\mathrm{NG108-15}$ and muscle cells were performed as described (MacDermot et al., 1979; Higashida et al., 1981a, 1984; Miki et al., 1981). Assays were carried out at $37^{\circ} \mathrm{C}$ in $2 \mathrm{ml}$ of serum-free DMEM. For stimulation by neurotensin (dissolved in $150 \mathrm{mM} \mathrm{NaCl}$ ), $2 \mu \mathrm{l}$ of the test solution with various concentrations of neurotensin $(0.1$ to $100 \mu \mathrm{M})$ were applied on the medium surface just $2 \mathrm{~mm}$ above a recording cell by using a Gilson micropipette. In some experiments, $100 \mu \mathrm{M}$ neurotensin in $0.1 \mathrm{~N} \mathrm{HCl}$ filled in dull-tip glass microelectrodes was iontophoretically applied to the hybrid cells by a microiontophoresis programmer (W-P Instruments, model 160).

\section{Results}

Characteristics of $\left[{ }^{3} H\right]$ neurotensin binding to NG10815 cells. [ $\left.{ }^{3} \mathrm{H}\right]$ Neurotensin bound specifically and reversibly to membrane fractions of NG108-15 cells at $25^{\circ} \mathrm{C}$. The specific binding rapidly increased with time and reached a plateau in about 2 to $3 \mathrm{~min}$ (Fig. $1 \mathrm{~A}$ ). The interaction of neurotensin with membrane fractions was analyzed as a pseudo-first-order reaction. When $L n$
$\left(\left[B_{\mathrm{eq}}\right] /\left[B_{\mathrm{eq}}\right]-[B]\right)$ was plotted as a function of time, a straight line was obtained (Fig. $1 A$, inset). Figure $1 B$ represents a time course of dissociation of $\left[{ }^{3} \mathrm{H}\right]$ neurotensin from NG108-15 cell membranes. Results have been plotted according to the equation $\operatorname{Ln}\left([B] /\left[B_{0}\right]\right)=-k_{-1} t$, in which $\left[B_{0}\right]$ is a concentration of bound peptides at time zero of dissociation (Fig., $1 B$, inset). A straight line was obtained, indicating that the dissociation of $\left[{ }^{3} \mathrm{H}\right]$ neurotensin is first order during at least the first $5 \mathrm{~min}$ of the reaction. Half-dissociation time $\left(t_{1 / 2}\right)$ was about $12.5 \mathrm{~min}$. The association $\left(k_{1}\right)$ and dissociation $\left(k_{-1}\right)$ rate constants were calculated from the two lines to be $0.3 \times$ $10^{6} \mathrm{M}^{-1} \mathrm{~min}^{-1}$ and $0.07 \times 10^{-3} \mathrm{~min}^{-1}$, respectively. $K_{\mathrm{d}}$ determined from the ratio $K_{-1} / K$ was $0.24 \mathrm{nM}$.

The concentration dependency of neurotensin binding at equilibrium was determined by adding various concentrations of $\left[{ }^{3} \mathrm{H}\right]$ neurotensin $(0.08$ to $40 \mathrm{nM})$. The specific binding was saturable (Fig. 2, inset), and Scatchard analysis of the data gave a straight line (Fig. 2). A dissociation constant $\left(K_{\mathrm{d}}\right)$ calculated from these data was $0.86 \mathrm{nM}$. This $K_{\mathrm{d}}$ value was of the same order as that determined from the association and dissociation rate constants (see above). The maximal binding capacity $\left(B_{\max }\right)$ of $250 \mathrm{fmol} / \mathrm{mg}$ of protein was obtained for NG108-15 cells, which corresponds to 7700 receptor sites per cell. The results indicate that NG108-15 cells possess a single population of neurotensin receptors.

Neurotensin and its analogues or related compounds were tested for their ability to replace $\left[{ }^{3} \mathrm{H}\right]$ neurotensin binding to the hybrid cell membranes. The competitive inhibition curve of the binding by unlabeled neurotensin was obtained and $\mathrm{IC}_{50}$ was about $0.6 \mathrm{nM}$ (Fig. $3 B$ ). The $K_{\mathrm{i}}$ of neurotensin was $0.26 \mathrm{~nm}$ when calculated by the equation, $K_{\mathrm{i}}=\mathrm{IC}_{50)} /\left(1+L / K_{\mathrm{d}}\right)$, which is very close to the $K_{\mathrm{d}}$ value $(0.24 \mathrm{nM})$ obtained from the kinetic experiments. The Hill coefficient for neurotensin was 1.1 (Fig. $3 A$ ), indicating no cooperative interaction between neurotensin binding sites. Of two neurotensin analogues tested, values of $K_{\mathrm{i}}$ and Hill coefficient for [D-Arg ${ }^{9}$ ]neurotensin were $0.22 \mathrm{~nm}$ and 1.0 , respectively, just as close as those for the parent neurotensin, while those for [D-Phe ${ }^{11}$ ]-neurotensin were $120 \mathrm{nM}$ and 2.1, respectively. Bradykinin and angiotensin II had no ability to replace $\left[{ }^{3} \mathrm{H}\right]$ neurotensin binding at the concentration of $10^{-7}$ to $10^{-5} \mathrm{M}$ (Fig. $3 B$ ). In addition, methionine-enkephalin, serotonin, dopamine, norepinephrine, isoproterenol, $\mathrm{ACh}, d$-tubocurarine, adenosine, diltiazem, prostaglandins $\left(\mathrm{A}_{1}, \mathrm{~B}_{1}, \mathrm{D}_{2}, \mathrm{E}_{1}, \mathrm{~F}_{2_{w}}, \mathrm{I}_{2}\right)$, and thromboxane $\mathrm{B}_{2}$ had no effect on the binding of $\left[{ }^{3} \mathrm{H}\right]$ neurotensin at the concentration of $10 \mu \mathrm{M}$.

Reagents influencing $\left[{ }^{3} \mathrm{H}\right]$ neurotensin binding of NG108-15 cell membranes were systematically exam ined. Divalent cations $\left(\mathrm{Ca}^{2+}\right.$ and $\left.\mathrm{Mg}^{2+}\right)$ produced no effect at up to $5 \mathrm{mM}$, whereas $50 \%$ inhibition was obtained by $100 \mathrm{mM} \mathrm{Na}{ }^{+}$as reported in mast cells (Lazarus et al., 1977a). GTP and $\mathrm{Gpp}(\mathrm{NH}) \mathrm{p}\left(10^{-4} \mathrm{M}\right)$ inhibited binding by 30 to $50 \%$, whereas ATP had no effect. Incubation with $0.5 \mathrm{mM} \mathrm{N}$-ethylmaleimide (NEM) reduced binding by approximately $50 \%$ of that seen in its absence.

$\left[{ }^{3} H\right]$ Neurotensin binding in parental clones. Values for the specific binding of neurotensin to membrane frac- 


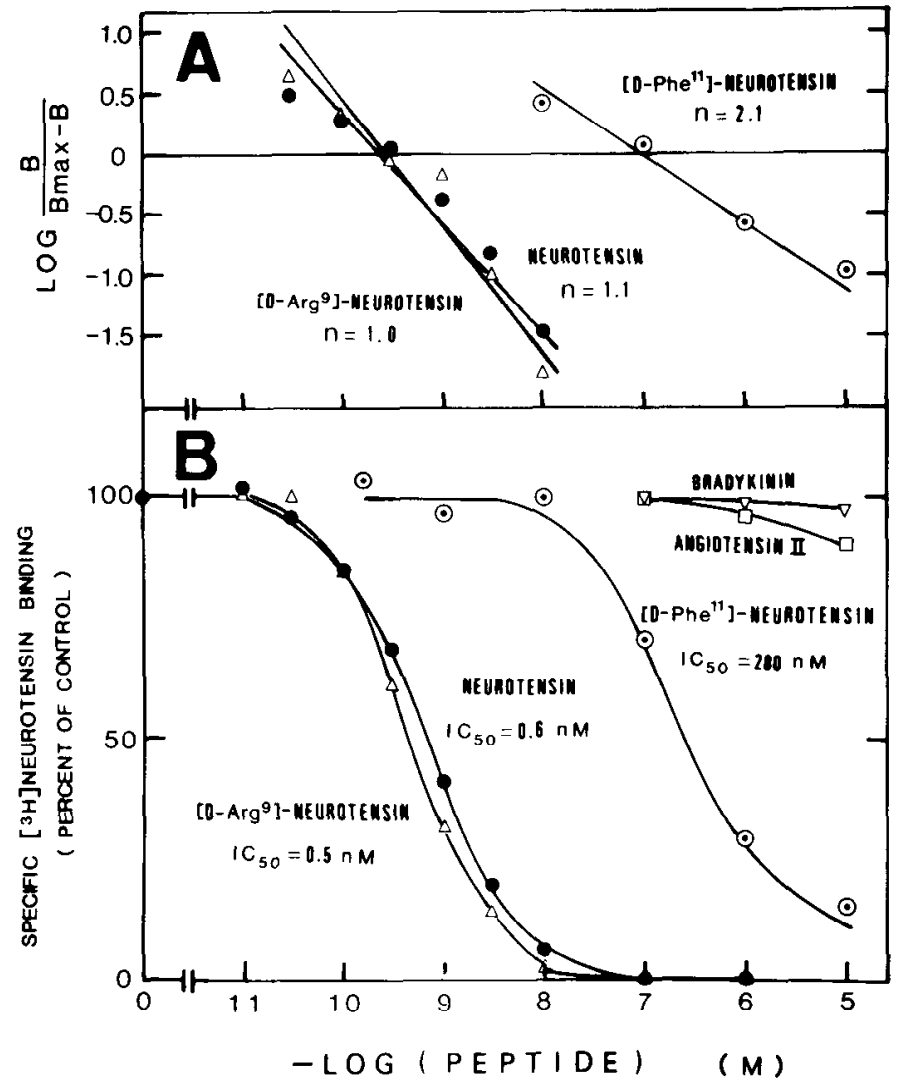

Figure 3. Hill plot and competitive inhibition of $\left[{ }^{3} \mathrm{H}\right]$ neurotensin binding by peptides. $A$, Pseudo-Hill value $\left({ }^{n} \mathrm{H}\right)$ of each of the competitors was obtained according to a Hill plot of the data in $B$. $B$, Membrane preparations of NG108-15 cells were incubated for $20 \mathrm{~min}$ at $25^{\circ} \mathrm{C}$ with $2 \mathrm{nM}\left[{ }^{3} \mathrm{H}\right]$ neurotensin and varying concentrations of unlabeled neurotensin $(\mathbf{O}),\left[\mathrm{D}-\mathrm{Arg}^{9}\right]$ neurotensin $(\triangle),\left[\mathrm{D}-\mathrm{Phe}^{11}\right]$ neurotensin $(\odot)$, angiotensin II $(\square)$, and bradykinin $(\nabla)$. All peptides were dissolved and diluted in $50 \mathrm{~mm}$ Tris- $\mathrm{HCl}$ buffer, $\mathrm{pH} 7.5$, containing $1 \%$ bovine serum albumin. Binding is expressed as the percentage of the binding of $\left[{ }^{3} \mathrm{H}\right]$ neurotensin in the absence of unlabeled peptides. Each point is the mean of triplicate experiments with duplicate determinations. Standard error of the mean is less than $3 \%$.

tions of mouse neuroblastoma N18TG-2 and rat glioma C6BU-1 cells were $2 \pm 3$ and $2 \pm 6 \mathrm{fmol} / \mathrm{mg}$ of protein ( \pm SEM), respectively, about 100 -fold lower than that for NG108-15 cells $(n=6)$.

$\left[{ }^{3} \mathrm{H}\right]$ Neurotensin binding in murine brains. In order to provide comparative evidence for neurotensin binding in NG108-15 cells, we studied synaptic membranes of murine brains. The concentration dependence of neurotensin binding at equilibrium was determined in the presence of increasing concentrations of $\left[{ }^{3} \mathrm{H}\right]$ neurotensin (Fig. 4, insets). The specific binding was found to be saturable. Scatchard plots of $\left[{ }^{3} \mathrm{H}\right]$ neurotensin binding to mouse and rat brain synaptosomal fractions showed two distinct binding sites (Fig. 4). The dissociation constants $\left(K_{\mathrm{d}}\right)$ for high and low affinity sites were $0.86 \mathrm{nM}$ and 13 $\mathrm{nM}$ in mouse brain synaptic membranes and $0.44 \mathrm{nM}$ and $19 \mathrm{nM}$ in rat brains, respectively. The calculated $B_{\max }$ at both affinity sites is also shown in Figure 4. The results indicate that the $K_{\mathrm{d}}$ of NG108-15 cells was very close to that of the high affinity $\left[{ }^{3} \mathrm{H}\right]$ neurotensin binding site of the murine brain synaptic membranes.
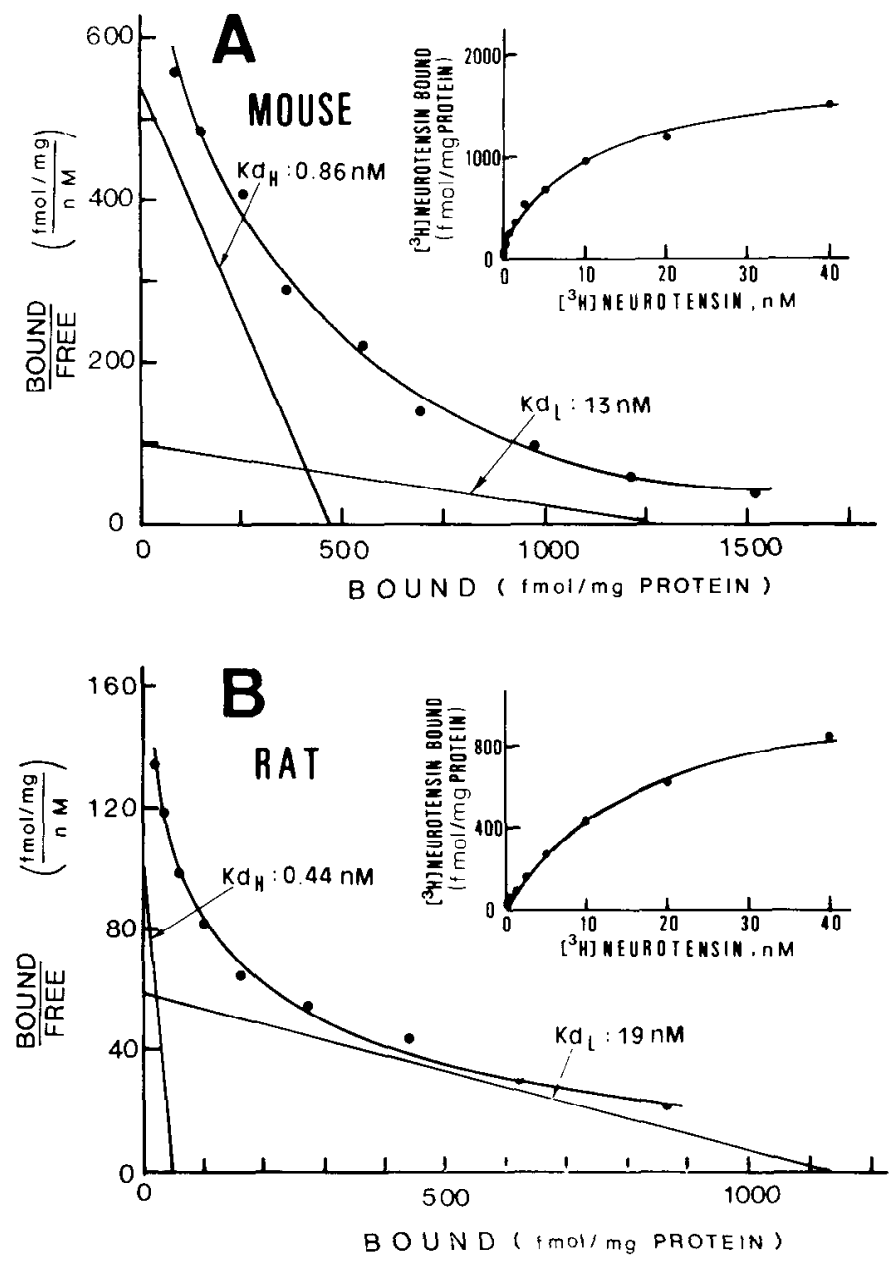

Figure 4. Scatchard analysis of $\left[{ }^{3} \mathrm{H}\right]$ neurotensin specific binding to synaptosomal fractions of murine brains. Membrane fractions from mouse and rat brains were incubated with various concentrations of $\left[{ }^{3} \mathrm{H}\right]$ neurotensin for $5 \mathrm{~min}$ at $25^{\circ} \mathrm{C}$ as described under "Materials and Methods." Protein concentrations of the membrane fractions from mouse and rat brains were 0.35 and $0.55 \mathrm{mg} /$ tube, respectively. Each point is the mean of duplicate determinations. Straight lines were fitted according to a two-site model. For synaptosome preparations of mouse brain: $K_{\mathrm{d}}$ (High), $0.86 \mathrm{nM} ; K_{\mathrm{d}}$ (Low), $13 \mathrm{nM} ; B_{\max }$ (High), $465 \mathrm{fmol} / \mathrm{mg}$ of protein; $B_{\max }$ (Low), $1250 \mathrm{fmol} / \mathrm{mg}$ of protein. For the preparation of rat brain: $K_{\mathrm{d}}$ (High), $0.44 \mathrm{nM}$; $K_{\mathrm{d}}$ (Low), $19 \mathrm{nM} ; B_{\max }$ (High), $45 \mathrm{fmol} / \mathrm{mg}$ of protein; $B_{\max }$ (Low), $1130 \mathrm{fmol} / \mathrm{mg}$ of protein. Specific $\left[{ }^{3} \mathrm{H}\right]$ neurotensin binding is also expressed as a function of free $\left[{ }^{3} \mathrm{H}\right]$ neurotensin concentration in the inset.

Effects of neurotensin on various responses in NG10815 cells. In order to clarify what kinds of cellular responses are mediated by neurotensin receptors, adenylate cyclase activity, phosphatidylinositol turnover and ${ }^{45} \mathrm{Ca}$ uptake rates, and membrane potential changes of NG108-15 cells were measured in the presence or absence of neurotensin.

Effect on adenylate cyclase. The mean adenylate cyclase activity of washed membrane fractions of NG108-15 cells in the presence of $10 \mu \mathrm{M}$ neurotensin was $29.8 \pm 0.8$ units (picomoles of $\left[{ }^{3} \mathrm{H}\right]$ cAMP formed per minute per milligram of protein \pm SEM, $n=3$ ), while the control activity was $30.8 \pm 2.5$ units. Neurotensin also had no effect on $\mathrm{PGE}_{1}$-stimulated cyclase activity $(n=3): 76.3 \pm 1.0$ units 
by $10 \mu \mathrm{M}$ neurotensin $+10 \mu \mathrm{M} \mathrm{PGE}_{1} ; 81.7 \pm 4.5$ units by $10 \mu \mathrm{M} \mathrm{PGE}_{1}$

Effect on phosphoinositol turnover. The incorporation of $\left[{ }^{32} \mathrm{P}\right]$ orthophosphate into various phospholipids of NG108-15 cells was measured after incubating them for 15 min with $\left[{ }^{32} \mathrm{P}\right]$ orthophosphate with or without the peptide. A labeling pattern showed no significant change in any fraction of phospholipids between cells incubated with and without $10 \mu \mathrm{M}$ neurotensin (Fig. 5), indicating no increase of phospholipid turnover such as phosphatidylinositol.

Effect on Ca uptake. The time course of calcium uptake by NG108-15 cells was also investigated. In a medium containing a physiologic concentration of potassium (5.4 $\mathrm{mM}$ ), NG108-15 cells took up $2.3 \mathrm{nmol}$ of ${ }^{45} \mathrm{Ca} / 5 \mathrm{~min} /$ $\mathrm{mg}$ of protein in the presence of $10 \mu \mathrm{M}$ neurotensin with a 5 to $10 \%$ increase over the control value, whereas a $410 \%$ increase in ${ }^{45} \mathrm{Ca}$ uptake was obtained in a solution containing $80 \mathrm{~mm} \mathrm{KCl}$.

Effects on membrane potentials. External application of as little as $1 \mu \mathrm{M}$ neurotensin on NG108-15 cells produced a long-lasting depolarization preceded by a transient hyperpolarization. This phenomenon is illustrated in Figure 6, $A$ and $B$, where the cells were stimulated by relatively high concentrations of neurotensin (10 and 100 $\mu \mathrm{M})$. The mean amplitudes of hyper- and depolarization by $10 \mu \mathrm{M}$ neurotensin, which were calculated from five samples that were evoked at the membrane potential level from -50 to $-60 \mathrm{mV}$, were $-6.6 \pm 6.2$ and $6 \pm 1.9$ $\mathrm{mV}( \pm \mathrm{SD})$, respectively. The initial hyperpolarization

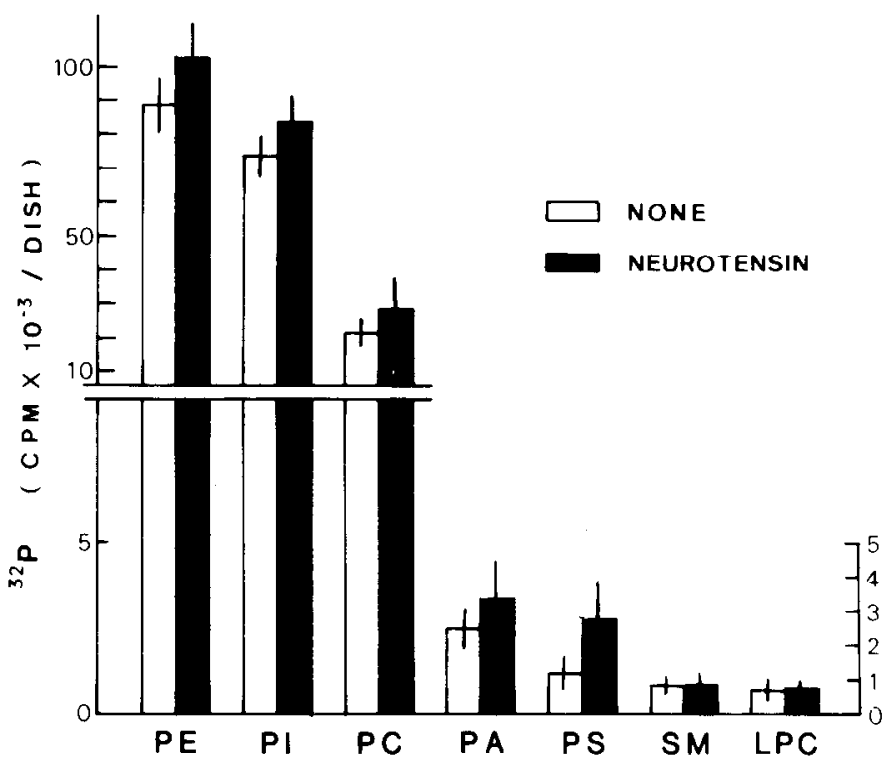

Figure 5. $\left[{ }^{32}\right] \mathrm{P}_{\mathrm{i}}$ incorporation into various phospholipids in resting and neurotensin-stimulated NG108-15 cells. NG108-15 cells were incubated in the absence and presence of neurotensin $(10 \mu \mathrm{M})$ for $15 \mathrm{~min}$. The reaction was terminated by adding 2 vol of chloroform/methanol, and phospholipids were quantitated as described under "Materials and Methods." The ordinate shows the radioactivity incorporated into the corresponding phospholipid during incubation. Each value is the mean \pm SEM of triplicate determinations. $P E$, phosphatidylethanolamine; $P I$, phosphatidylinositol; $P C$, phosphatidylcholine; $P A$, phosphatidic acid; $P S$, phosphatidylserine; $S M$, sphingomyelin; $L P C$, lysophosphatidylcholine. lasted for about $10 \mathrm{sec}$, while depolarization lasted for 30 to $60 \mathrm{sec}$. Membrane resistance decreased during hyperpolarization by neurotensin. During subsequent depolarization, the conductance recovered to the control level, although the apparent resistance was lower in some cases. Action potentials evoked by current injection into NG108-15 cells were commonly suppressed during hyperpolarization (Fig. 6A). Recovery in producing action potentials was sometimes observed from the middle point of the rising phase from the bottom of the hyperpolarization. As seen in Figure $6 B$, an apparent increase in amplitude of anodal break spikes, which were stimulated by a subthreshold intensity, was observed during depolarization, indicating that NG108-15 cell membranes are highly excitable during neurotensin-evoked depolarization. Iontophoretic applications of neurotensin elicited this same biphasic response feature (Fig. 6C). During hyperpolarization the generation of action potentials was inhibited and the membrane conductance was increased. During depolarization action potentials were elicited and membrane conductance recovered to that level seen before stimulation.

Effects of neurotensin on neuromuscular transmission. Miniature endplate potentials (MEPPs) were recorded from rat striated myotubes co-cultured with NG108-15 cells for 3 days in $10 \mu \mathrm{M} \mathrm{PGE}$ and $1 \mathrm{~mm}$ theophylline. An external application of $1 \mu \mathrm{M}$ neurotensin to the junctions between the hybrid and muscle cells produced a significant increase in MEPP frequency. A typical example is illustrated in Figure 7, where a 16-fold facilitation in MFPP frequency lasted for $30 \mathrm{sec}$.

\section{Discussion}

The results demonstrate that NG108-15 hybrid cells possess a single population of specific binding sites for neurotensin. There is good agreement between the kinetic $(0.86 \mathrm{nM})$ and equilibrium $(0.24 \mathrm{nM})$ determinations of the $K_{\mathrm{d}}$ of NG108-15 cells. These values were very close to those for the high affinity binding sites in synaptic membranes of mouse $(0.86 \mathrm{nM})$ and rat $(0.44 \mathrm{nM})$ brains (Fig. 4). Recently, two binding sites (0.1 and $4.7 \mathrm{nM})$ in rat synaptic membranes have been reported by Vincent et al. (1982) using $\left.{ }^{125} \mathrm{I}\right]$ monoiode-Trp ${ }^{11}$-neurotensin. The dissociation constants $\left(K_{\mathrm{d}}\right)$ of $\left[{ }^{125} \mathrm{I}\right]$ neurotensin and $\left[{ }^{3} \mathrm{H}\right]$ neurotensin binding sites described by several groups (Kitabgi et al., 1977, 1980; Uhl et al., 1977) have been $\sim 3 \mathrm{nM}$, the value of which is discrepant from the NG10815 cell data. These initial studies could not detect the higher affinity component, since initial radioligands possessed insufficient specific activity to detect this component easily.

In both parental cell lines, N18TG-2 and C6BU-1, the number of specific binding sites for neurotensin was extremely low. This indicates that fusion of both parental cells yielded increased expression of neurotensin receptors, as seen in opiate receptors of NG108-15 cells (Klee and Nirenberg, 1974). The neurotensin receptor density (7700 sites/cell) is the lowest among the known receptor numbers in NG108-15 cells: 300,000 opiate receptors (Klee and Nirenberg, 1974); 150,000 to $250,000 \mathrm{PGE}_{1}$ receptors (Kenimer, 1982); 60,000 $\alpha$-adrenergic receptors (S. Ayukawa and M. Nirenberg, unpublished results); 

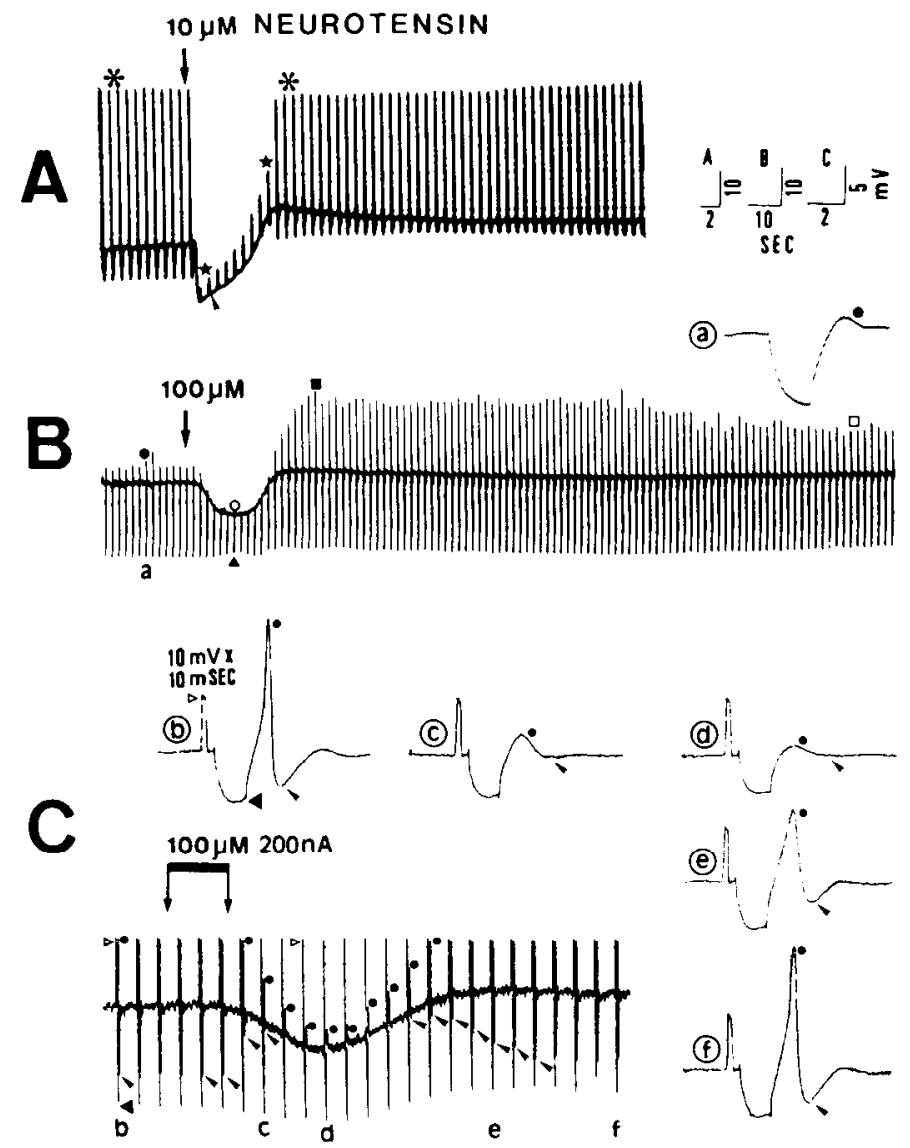

Figure 6. Effects of neurotensin on the membrane potential of NG108-15 cells. $A$, The pen recording trace showing the time course of typical response to $2 \mu \mathrm{l}$ of $10 \mu \mathrm{M}$ neurotensin in 150 $\mathrm{mM} \mathrm{NaCl}$ applied to the surface of $2 \mathrm{ml}$ of DMFM at the point of the arrow. Full scale action potentials (upper deflections of membrane potentials indicated by $*$ ) were evoked by application of depolarizing current pulses $(1 \mathrm{nA})$ of $60 \mathrm{msec}$ duration. Lower deflections of membrane potentials indicate afterhyperpolarization of action potentials. Note inhibition of spikes (stars) and afterhyperpolarization (arrowhead) during hyperpolarizating response by neurotensin. $B$, Similar biphasic responses produced by supramaximal stimulation $(4 \mu \mathrm{l}$ of 100 $\mu \mathrm{M})$ of neurotensin at the point of the arrow. Changes in the input membrane resistance were monitored by repetitive and hyperpolarizing test pulses of $0.3 \mathrm{nA}$ amplitude and of $100 \mathrm{msec}$ duration, as shown in a specimen response at the indicated point $(a)$. The clear decrease in lower deflections of membrane potentials during hyperpolarizing response by neurotensin (solid triangle) means increase in membrane conductance. Note the recovery of the lower deflection during the depolarizing period by neurotensin with slight increase $(10 \%)$. The upper deflections of membrane potentials are the small off (anodal break)-responses by subthreshold current stimuli (solid circles). The complete loss of off-response is apparent in nine stimuli during hyperpolarizing response by neurotensin (open circle). A great increase in size of anodal break action potentials is elicited by the same strength of current pulses as during the previous depolarizing response by neurotensin (solid square). The enhancement of off-spikes continued for about $130 \mathrm{sec}$ and their size gradually decreased (open square). Note that the dose acting on the cell membrane would be much lower by diffusion than the concentration in the test solution. The final equilibrium concentration of neurotensin in $A$ and $B$ is about 10 and $200 \mathrm{nM}$, respectively. $C$, Iontophoretic application of neurotensin to a hybrid cell induced initially hyperpolarization and subsequently depolarization. The iontophoretic pipette con-

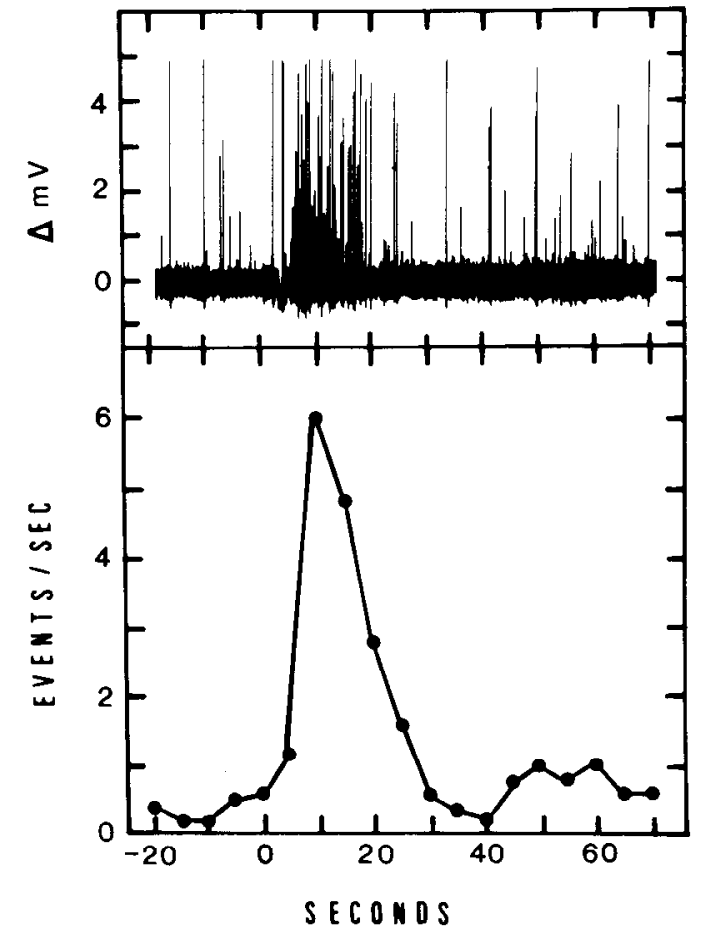

Figure 7. Neurotensin-dependent increase in frequency of MEPPs in a muscle cell. Top, Trace of an AC recording at high gain was obtained with an intracellular microelectrode from a rat myotube which had been co-cultured for 3 days and had made junctions with NG108-15 hybrid cells. Bottom, A plot of the number of spontaneous and neurotensin-evoked MEPPs per sec. Two microliters of a solution containing $10 \mu \mathrm{M}$ neurotensin, $0.1 \%$ ethanol, and $150 \mathrm{mM} \mathrm{NaCl}$ were applied to the hybrid cell at time zero.

32,000 muscarinic ACh receptors (Burgermeister et al., 1978).

As $\left[{ }^{3} \mathrm{H}\right]$ neurotensin binding is reduced by NEM, sulfhydryl groups may contribute to the binding. The treatment of the NG108-15 cell membrane fractions with neuraminidase, $\beta$-galactosidase, and hyaluronidase did not affect the binding capacity (unpublished results), indicating that carbohydroxy moieties may not be directly related to the binding of neurotensin.

Our preliminary results, showing that the heat and trypsin pretreatment of membrane fractions greatly reduced the radioligand binding, suggest the proteinous nature of the binding site. We tried to solubilize receptor molecules in brain membranes by treatment with $0.5 \%$

tained a solution of $100 \mu \mathrm{M}$ neurotensin in $0.1 \mathrm{~N} \mathrm{HCl}$, and a current of $200 \mathrm{nA}$ was passed for $3 \mathrm{sec}$ (shown at the thick bar). The membrane excitability and conductance were monitored by periodically applying 1-nA hyperpolarizing pulses, as shown in examples of fast-speed recordings at the indicated points from $b$ to $f$. Calibration pulses of $10 \mathrm{mV}$ and $10 \mathrm{msec}$ were applied in each stimulation (open triangles). The lower deflection (solid triangles) was decreased during hyperpolarization (in $c$ and $d$ ) and recovered to the initial size during depolarization (in $e$ and $f$ ) by neurotensin. Anodal break spikes (solid circles) decreased in size during hyperpolarization, even though the same current pulses were applied throughout (in $c, d$, and $e)$, and then recovered to the original amplitude as shown in $f$. Afterhyperpolarization of action potentials (arrowheads) disappeared during hyperpolarization by neurotensin. 
CHAPS (a zwitterionic detergent), and in these experiments radioactivities could be recovered in soluble fractions. Experiments to estimate the molecular weight of neurotensin receptors is now proceeding by centrifugation in a linear sucrose density gradient (5 to $20 \%$ ).

The neurotensin receptors were strict in ligand specificity, because the binding of $\left[{ }^{3} \mathrm{H}\right]$ neurotensin to NG10815 cells was not affected by a large excess of unlabeled angiotensin II and bradykinin. In mast cells bradykinin is able to compete with neurotensin $100 \%$ (Lazarus et al., 1977b). Unlike its activity in mast cells, the increased binding affinity by $\left[\mathrm{D}-\mathrm{Arg}^{9}\right]$-neurotensin was not observed in the hybrid cells. Thus, the nature of neurotensin receptors in NG108-15 cells is different from those in mast cells in these respects.

It is clear that neurotensin receptors of NG108-15 cells couple neither with adenylate cyclase, as shown in longitudinal intestinal muscle cells (Kitabgi and Freychet, 1979), nor with the pathway of phospholipid turnover proposed by Michell (1975). Our recent experiments have revealed that neurotensin does not change phosphatidylinositol 4,5-bisphosphate (Creba et al., 1983) levels in NG108-15 cells, although a rapid breakdown of phosphatidylinositol 4,5-bisphosphate is triggered by bradykinin (K. Yano, H. Higashida, R. Inoue, and Y. Nozawa, manuscript in preparation).

Neurotensin initially hyperpolarized and then depolarized NG108-15 cells. Such changes have been reported by bradykinin in NG108-CC-25 hybrid cells (Reiser and Hamprecht, 1982) and by $\mathrm{PGD}_{2}$ in NG108-15 cells (Higashida et al., 1984). As changes in membrane conductance during sustained depolarization by neurotensin were not significant, what ions contribute in generation of sustained depolarization is not known. However, when $10 \mathrm{mM} \mathrm{CoCl}_{2}$ was added in the recording medium, the neurotensin-evoked depolarizing response disappeared, although hyperpolarization was resistant $(H$. Higashida and M. Nirenberg, unpublished data), and replacement of $\mathrm{Na}^{+}$as well as $\mathrm{Ca}^{2+}$ in the recording medium depressed the depolarizing response. These preliminary observations suggest that both $\mathrm{Na}$ and $\mathrm{Ca}$ ions may be required to produce sustained depolarization.

The apparent increase in spike height during the depolarizing period (Fig. $6 \mathrm{~B}$ ) could be due to the increased utility of $\mathrm{Ca}^{2+}$ or $\mathrm{Na}^{+}$in spike genesis, because action potentials of the cells are a mixture of both $\mathrm{Na}$ and $\mathrm{Ca}$ components (Reiser et al., 1977; Fishman and Spector, 1981). The clear decrease in membrane resistance seen during hyperpolarization by neurotensin suggests increased involvement of an ion flux. By measuring the responses at different concentrations of $\left[\mathrm{K}^{+}\right]_{0}$, the hyperpolarization induced by bradykinin in NG108-CC-25 cells (Resier and Hamprecht, 1982) has been shown to be caused by an increase in $\mathrm{K}$ conductance. A similar mechanism could occur in NG108-15 cells involving neurotensin. Thus, neurotensin receptors would link to ion channels, probably of $\mathrm{K}^{+}, \mathrm{Na}^{+}$, or $\mathrm{Ca}^{2+}$.

Modulation of neuromuscular transmission was clearly demonstrated by application of neurotensin at synaptic sites between NG108-15 and muscle cells (Fig. 7). In these synapses in culture, modulation of synaptic transmission has been demonstrated by serotonin (Christian et al., 1978; MacDermot et al., 1979), PGF ${ }_{2, k}$ (Christian et al., 1978), and $\mathrm{PGD}_{2}$ (Higashida et al., 1984). Characteristics of cholinergic transmission from the hybrid cells were partly clarified by Nelson et al. (1976) and Higashida et al. (1978). However, questions about ACh storage sites and modes of quantum or non-quantum release of $\mathrm{ACh}$ in the hybrid cells remain unsolved. Therefore, it is difficult to define which type (bell or skew) of cholinergic transmission (Thesleff and Molgo, 1983) is accelerated by neurotensin at hybrid-myotube synapses.

In summary, a single population of neurotensin receptor sites has been proven to exist in NG108-15 hybrid cells. These receptors exhibited high affinity for neurotensin among small peptidergic neurohormones. The receptors may link to ionic channels rather than to metabolic processes and mediate membrane excitation and facilitation of synaptic transmission. As neurotensin receptors of NG108-15 cells resemble those of synaptosomal fractions of the murine brains, the neurotensin receptor with this coupling mode in NG108-15 cells seems to possess characteristics of neurotensin receptors functioning in the CNS.

\section{References}

Burgermeister, W., W. L. Klein, M. Nirenberg, and B. Witkop (1978) Comparative binding studies with cholinergic ligands and histrionicotoxin at muscarinic receptors of neural cell lines. Mol. Pharmacol. 14: 751-767.

Carraway, R., and S. E. Leeman (1973) The isolation of a new hypotensive peptide, neurotensin, from bovine hypothalami. J. Biol. Chem. 248: 6854-6861.

Christian, C. N., P. G. Nelson, P. Bullock, D. Mullinax, and M. Nirenberg (1978) Pharmacological responses of cells of a neuroblastoma $\times$ glioma hybrid clone and modulation of synapses between hybrid cells and mouse myotubes. Brain Res. 147: 261-276.

Creba, J. A., C. P. Dowes, P. T. Hawkins, G. Brewster, R. H. Michell, and C. J. Kirk (1983) Rapid breakdown of phosphatidylinositol 4-phosphate and phosphatidylinositol 4,5-biphosphate in rat hepatocytes stimulated by vasopressin and other $\mathrm{Ca}^{2+}$-mobilizing hormones. Biochem. J. 212: 733-747.

Emson, P. C., M. Goedert, B. Williams, M. Ninkovic, and S. P. Hunt (1982) Neurotensin: Regional distribution, characterization, and inactivation. Ann. N. Y. Acad. Sci. 400: 198215.

Feldman, H. A. (1972) Mathematical theory of complex ligandbinding systems at equilibrium: Some methods for parameter fitting. Anal. Biochem. 48: 317-338.

Fishman, M. C., and 1. Spector (1981) Potassium current suppression by quinidine reveals additional calcium currents in neuroblastoma cells. Proc. Natl. Acad. Sci. U. S. A. 78: $5245-5249$.

Gray, E. G., and V. P. Whittaker (1962) The isolation of nerve endings from brain: An electron-microscopic study of cell fragments derived by homogenization and centrifugation. J. Anat. 90: 79-96.

Haga, T., and K. Haga (1981) Characterization by [3H]dihydroergocriptine binding of alpha-adrenergic receptors in neuroblastoma $\times$ glioma hybrid cells. J. Neurochem. 36 : 11521159.

Henry, J. L. (1982) Electrophysiological studies on the neuroactive properties of neurotensin. Ann. N. Y. Acad. Sci. 400: 216-227.

Higashida, H., S. P. Wilson, M. Adler, and M. Nirenberg (1978) Synapse formation by neuroblastoma and hybrid cell lines. Soc. Neurosci. Abstr. 4: 591. 
Higashida, H., T. Kato, K. Kano-Tanaka, M. Okuya, A. Miyake, and T. Tanaka (1981a) Proliferation and synapse formation of neuroblastoma $\times$ glioma hybrid cells: Effect of glia maturation factor. Brain Res. 214: 287-299.

Higashida, H., N. Miki, T. Tanaka, K. Kato, T. Nakano, T. Nagatsu, and K. Kano-Tanaka (1981b) Receptor-associated changes of the catecholamine-sensitive adenylate cyclase in glioma cells doubly transformed with Moloney sarcoma virus. J. Cell. Physiol. 110: 107-113.

Higashida, H., Y. Nakagawa, and N. Miki (1984) Facilitation of synaptic transmission by prostaglandin $\mathrm{D}_{2}$ at synapses between NG108-15 hybrid and muscle cells. Brain Res. 295: $113-119$.

Iversen, L. L., S. D. Iversen, F. Bloom, C. Douglas, M. Brown, and W. Vale (1978) Calcium-dependent release of somatostatin and neurotensin from rat brain in vitro. Nature 273: 161-163.

Kahn, D. J., J. C. Mitrius, and D. C. U'Prichard (1982) Alpha ${ }_{2}-$ adrenergic receptors in neuroblastoma $\times$ glioma hybrid cells. Characterization with agonist and antagonist radioligands and relationship to adenylate cyclase. Mol. Pharmacol. 21: 1726.

Kenimer, J. G. (1982) Desensitization of $\mathrm{PGE}_{1}$ receptors in neuroblastoma-glioma hybrid cells. Prostaglandins 23: 311 318.

Kenimer, J. G., and M. Nirenberg (1981) Desensitization of adenylate cyclase to prostaglandin $\mathrm{E}_{1}$ or 2-chloroadenosine. Mol. Pharmacol. 20: 585-591.

Kitabgi, P., and P. Freychet (1979) Neurotensin: Contractile activity, specific binding, and lack of effect on cyclic nucleotides in intestinal smooth muscle. Eur. J. Pharmacol. 55: 3542.

Kitabgi, P., R. Carraway, J. V. Rietschoten, C. Cranier, J. L. Morgat, A. Menez, S. Leeman, and P. Freychet (1977) Neurotensin: Specific binding to synaptic membranes from rat brain. Proc. Natl. Acad. Sci. U. S. A. 74: 1846-1850.

Kitabgi, P., C. Poustis, C. Granier, J. V. Rietschoten, J. Rivier, J. -L. Morgat, and P. Freychet (1980) Neurotensin binding to extraneural and neural receptors: Comparison with biological activity and structure-activity relationships. Mol. Pharmacol. 18: 11-19.

Klee, W. A., and M. Nirenberg (1974) A neuroblastoma $\times$ glioma hybrid cell line with morphine receptors. Proc. Natl. Acad. Sci. U. S. A. 71: 3474-3477.

Lazarus, L. H., M. H. Perrin, and M. R. Brown (1977a) Mast cell binding of neurotensin. I. Iodination of neurotensin and characterization of the interaction of neurotensin with mast cell receptor sites. J. Biol. Chem. 252: 7174-7179.

Lazarus, L. H., M. H. Perrin, M. R. Brown, and J. E. Rivier (1977b) Mast cell binding of neurotensin. II. Molecular conformation of neurotensin involved in the stereospecific binding to mast cell receptor sites. J. Biol. Chem. 252: 7180-7183.

Leeman, S. E., and R. E. Carraway (1982) Neurotensin: Discovery, isolation, characterization, synthesis and possible physiological roles. Ann. N. Y. Acad. Sci. 400: 1-16.

Lowry, O. H., N. J. Rosebrough, A. L. Farr, and R. J. Randall (1951) Protein measurement with the Folin phenol reagent. J. Biol. Chem. 193: 265-275.

MacDermot, J., H. Higashida, S. P. Wilson, H. Matsuzawa, J. Minna, and M. Nirenberg (1979) Adenylate cyclase and acetylcholine release regulated by separate serotonin receptors of somatic cell hybrids. Proc. Natl. Acad. Sci. U. S. A. 76: $1135-1139$.

Marwaha, J., B. Hoffer, and R. Freedman (1980) Electrophysiological actions of ncurotensin in rat cercbellum. Reg. Peptides $1: 115-125$.

McCarthy, P. S., R. J. Waller, H. Yajima, K. Mitagawa, and G. $H$. Woodruff (1979) The action of neurotensin on neurons in the nucleus accumbens and cerebellum of the rat. Gen. Pharmacol. 10: 331-333.
Michell, R. H. (1975) Inositol phospholipids and cell surface receptor function. Biochim. Biophys. Acta 415: 81-147.

Miki, N., Y. Hayashi, and H. Higashida (1981) Characterization of chick gizzard extract that promotes neurite outgrowth in cultured ciliary neurons. J. Neurochem. 37: 627-633.

Miletic, V., and M. Randic (1979) Neurotensin excites cat spinal neurones located in laminae I-III. Brain Res. 169: 600-604.

Nelson, P. G., C. Christian, and M. Nirenberg (1976) Synapse formation between clonal neuroblastoma $\times$ glioma hybrid cells and striated muscle cells. Proc. Natl. Acad. Sci. U. S. A. 73: $123-127$.

Nirenberg, M., S. Wison, H. Higashida, A. Rotter, K. Krueger, N. Busis, R. Ray, J. Kenimer, and M. Adler (1983) Modulation of synapse formation by cyclic adenosine monophosphate. Science 222: 794-799.

Ohsako, S., and T. Deguchi (1981) Stimulation by phosphatidic acid of calcium influx and cyclic GMP synthesis in neuroblastoma cells. J. Biol. Chem. 256: 10945-10948.

Reiser, G., and B. Hamprecht (1982) Bradykinin induces hyperpolarizations in rat glioma cells and in neuroblastoma $\times$ glioma hybrid cells. Brain Res. 239: 191-199.

Reiser, G., R. Heumann, W. Kemper, E. Lautenschlager, and B. Hamprecht (1977) Influence of cations on the electrical activity of neuroblastoma $\times$ glioma hybrid cells. Brain Res. 130: 495-504.

Rivier, J. E., L. H. Lazarus, M. H. Perrin, and M. R. Brown (1977) Neurotensin analogues. Structure-activity relationship. J. Med. Chem. 20: 1409-1412.

Sabol, S. L., and M. Nirenberg (1979) Regulation of adenylate cyclase of neuroblastoma $\times$ glioma hybrid cells by $\alpha$-adrenergic receptors. I. Inhibition of adenylate cyclase mediated by receptors J. Biol. Chem. 254: 1913-1920.

Sawada, S., S. Takada, and C. Yamamoto (1980) Electrical activity recorded from thin sections of the bed nucleus of the stria terminalis, and the effects of neurotensin. Brain Res. 188: $578-581$.

Seybold, V., and B. Maley (1981) Ultrastructural localization of neurotensin-like immuno-reactivity in the dorsal horn of the rat spinal cord. Soc. Neurosci. Abstr. 7: 59

Sharma, S. K., M. Nirenberg, and W. L. Klee (1975) Morphine receptors as regulators of adenylate cyclase activity. Proc. Natl. Acad. Sci. U. S. A. 72: 590-594.

Thesleff, S., and J. Molgo (1983) A new type of transmitter release at the neuromuscular junction. Neuroscience 9:1-8.

Traber, J., K. Fischer, C. Buchen, and B. Hamprecht (1975a) Muscarinic response to acetylcholine in neuroblastoma $\times$ glioma hybrid cells. Nature 255: 558-560.

Traber, J., K. Fischer, S. Latzin, and B. Hamprecht (1975b) Morphine antagonizes action of prostaglandin in neuroblastoma and neuroblastoma $\times$ glioma hybrid cells. Nature 253: $120-122$.

Uhl, G. R., and S. H. Snyder (1976) Regional and subcellular distributions of brain neurotensin. Life Sci. 19: 1827-1832.

Uhl, G. R., J. P. Bennett, Jr., and S. H. Snyder (1977) Neurotensin, a central nervous system peptide: Apparent receptor binding in brain membranes. Brain Res. 130: 299-313.

Vincent, J. -P., J. Mazella, C. Poustis, F. Checler, P. Kitabgi, C. Labbe, C. Granier, and J. V. Rietschoten (1982) Monoiodo$\operatorname{Trp}^{11}$-neurotensin, a new ligand to study the interaction of neurotensin with its receptor. Ann. N. Y. Acad. Sci. 400: 436-437.

Yano, K., H. Hattori, A. Imai, and Y. Nozawa (1983) Modification of positional distribution of fatty acids in phosphati dylinositol of rabbit neurophils stimulated with formylmethionyl-phenylalanine. Biochim. Biophys. Acta 752: 137-144.

Young, W. S., III, G. R. Uhl, and M. J. Kuhar (1978) Iontophoresis of neurotensin in the area of the locus coeruleus. Brain Res. 150: 431-435. 